\title{
The School Library as a Sexual Health Learning Environment
}

\author{
Jennifer Richey, Ph.D. \\ Texas Woman's University \\ School of Library \& Information Studies \\ Stoddard Hall, Room 404 \\ P.O. Box 425438 \\ Denton, TX 76204-5438 \\ United States of America \\ Jrichey1@twu.edu
}

\begin{abstract}
In Northern Europe and the United States, approximately half of adolescents have engaged in sexual activity by the age of 18 years, but attitudes, behaviors, and outcomes among adolescents in the two geographic areas differ greatly. Although multiple factors contribute to decision-making and although adolescents receive sexual health information through myriad information channels, one commonality exists between the two geographic areas: the school library. This paper presents the findings of two studies exploring the role of high school librarians in Texas as sexual health information providers and motivators and barriers to information provision, as perceived by district-level library coordinators, high school principals, and high school librarians. Results suggest the librarian potentially plays this role, and more motivators for information provision exist than do barriers; as such, the school library potentially serves as a sexual health learning environment.
\end{abstract}

Keywords: Adolescent sexual health; Sexual health information; School libraries; Health information literacy

\section{Introduction}

Despite approximately the same percentage of Northern European and American adolescents engaging in sexual activity by the age of 18 years, American adolescents engage in riskier behaviors and express unhealthier attitudes than their Northern European counterparts. Within the United States, Texas ranks among the highest in both adolescent birth rates and adolescent pregnancies. Information sources as well as educational programs can influence adolescents' sexual attitudes and behaviors. Based on guidelines from the International Association of School Librarians (IASL), the American Library Association (ALA), and the American Association for School Librarians (AASL), the school library can serve as a sexual health learning environment for adolescents, where adolescents can receive current, accurate, reliable, and balanced sexual health information from certified school librarians. 
This paper shares the results of two studies exploring high school librarians as sexual health information providers and concludes with a discussion about the school library as a sexual health learning environment.

\section{Literature Review}

\section{Adolescent Sexual Behavior in Europe, America, and Texas: A Comparison}

The percentages of adolescents in Northern Europe and the United States of America engaging in sexual intercourse are comparable, but the behaviors and outcomes vary greatly. Exact years of comparison are not available for European countries, but Advocates for Youth (2008) report that in varying years during the 2000's, the rate of adolescent pregnancies, birth rates, and HIV/STI rates in France, the Netherlands, and Germany were considerably lower than those in the United States. Adolescents in these European countries were more likely to use some form of birth control compared to their American counterparts.

Although approximately the same percentage of Texas adolescents have sex as do adolescents across the United States (Centers for Disease Control and Prevention, 2014a), the outcomes also vary greatly. In 2010, out of 50 states, Texas ranked third in nation for number of adolescent pregnancies at a rate of 73.0 per 1000 compared to the national rate of 57.4 births per 1000 . The same year, Texas ranked fourth in the nation for birth rates at a rate of 52.0 per 1000 compared to the national rate of 34.4 births per 1000 (Kost \& Henshaw, 2014). Additionally, $19.0 \%$ of Texas adolescents report not using any form of birth control compared to the national average of $13.7 \%$ (Centers for Disease Control and Prevention, 2014b).

Adolescent pregnancies in America have detrimental social, health, economic, and educational repercussions for the mothers, their children, and society as a whole. For the children, there are increased risks of health problems, learning disabilities, and becoming victims of neglect or abuse. For the adolescent mothers, there are increased risks of health problems, living in poverty, and not completing high school (Hoffman, Foster, \& Furstenberg 1993; Moore, Morrison, \& Greene 1997; Kirby 2007). Additionally, American adolescents have reduced access to health care (Alan Guttmacher Institute, 2001), potentially further contributing to or exacerbating existing health problems. Nationally taxpayers spend approximately $\$ 9.4$ billion each year on costs related to adolescent pregnancy (National Campaign to Prevent Teen and Unplanned Pregnancy, 2015a), and Texas taxpayers spend approximately $\$ 1.1$ billion annually (National Campaign to Prevent Teen and Unplanned Pregnancy, 2015b).

\section{Sexual Health Information Sources and Education}

American adolescents typically are provided with sexual health information through both formal and informal sources. Examples of formal sources include programs organized through schools, churches, health agencies, etc., and examples of informal sources include family members, peers, and various media formats like television, books, movies, and the Web (Cornog \& Perper, 1996; Bleakley, Hennessy, Fishbein, \& Jordan, 2009).

A positive correlation exists between source type and sexual attitudes and behaviors: when adolescents receive information from formal sources, they are less likely to engage in risky 
behaviors and more likely to express cautious attitudes than when receiving information from informal sources (Somers \& Surmann 2005; Bleakley, Hennessy, Fishbein, \& Jordan, 2009). Additionally, providing adolescents with sexual health information early in the adolescent stage also reduces an adolescent's likelihood of engaging in risk-taking behaviors (Somers \& Surmann 2005).

Informal sources can vary in accuracy, reliability, and currency, thus promoting misconceptions and/or misinforming the information receiver. Compared to adolescents receiving information from formal sources, adolescents receiving information from informal sources are more likely to engage in riskier sexual behaviors and express less cautious attitudes and beliefs (Somers \& Surmann 2005; Bleakley, Hennessy, Fishbein, \& Jordan, 2009).

When American schools choose to offer sexual education programs, they are of two primary types: comprehensive programs and abstinence education programs. Comprehensive programs teach "...a broad set of topics related to sexuality including human development, relationships, decision making, abstinence, contraception, and disease prevention" (Sexuality Information and Education Council of the United States, n.d.). A meta-analysis examining the long-term effects of all sexual health education programs suggest comprehensive programs have more positive effects on adolescent behaviors and attitudes than do abstinence programs (Kirby, 2007).

The Social Security Administration branch of the United States government promotes abstinence education, which is defined as "an educational or motivational program which...teaches abstinence from sexual activity outside of marriage...[and] is the expected standard of human sexual activity" (Social Security Administration, 2009). The type of sexual health program varies by geographical region, state, and sometimes even within a state (Landry, Darroch, Singh, \& Higgins, 2003). Texas does not require schools to teach sexual education, but if schools do provide sexual education, abstinence must be stressed (Alan Guttmacher Institute, 2015).

In Northern Europe, comprehensive sexual education is standard (Boonstra, 2011). Educational programs encourage adolescents to use information and critical thinking skills to decide if, and, or when each individual is ready to enter into a sexual relationship, compared to America where the overall goal is to prevent adolescents from engaging in sexual behaviors for as long as possible, preferably until marriage (Santelli, Sandfort, \& Orr, 2000; Singh \& Darroch, 2008).

Providing adolescents with accurate, current, reliable, and balanced sexual health information promotes healthier sexual attitudes and behaviors compared to adolescents receiving limited or no information. The school library can provide such information, and, in turn, promote healthier attitudes and behaviors.

\section{Why school libraries as a sexual health learning environment?}

Libraries as sexual health learning environments date back at least to the 1800's with the "Enfer" (hell) collection in the Bibliothèque Nationale in Paris, France. Since then, libraries in general have met the sexual health information needs of their patrons of all ages, modifying 
and updating collections to reflect changing social issues and health information needs (Cornog \& Perper, 1996).

The International Association of School Librarianship (IASL) identifies the school library as an environment where students learn life-long literacy and technology skills transferable beyond curricular needs, by which students are able "to locate and evaluate information to answer educational and recreational needs and interests" (1993). School librarians teach adolescent patrons life-long literacy skills, including how to locate, evaluate, and use information from a range of sources answering curricular and personal needs and interests. Personal needs include sexual health information. Materials and resources include both print and digital, and access potentially includes $24 / 7$ availability.

According to the American Library Association's Bill of Rights (2015), all libraries should provide resources and materials "for the interest, information, and enlightenment of all people of the community the library serves...[and] should provide materials and information presenting all points of view on current and historical issues" (ALA, 2015). Two goals of the American Association for School Librarians (AASL), a division of ALA, identify the school library as a place to "connect learners with ideas and information, and [to] prepare students for life-long learning, informed decision-making" (AASL, 2015). American adolescents have expressed a need for more information than they have received in existing programs (Hoff \& Greene, 2000). Depending on the school, curriculum may also include sexual health information.

School libraries serve as a learning environment and school librarians serve as teachers providing access to current, reliable, and balanced information. Sexual health information falls within the parameters of the curricular and personal information needs of adolescents; thus, the school library potentially serves as a sexual health learning environment, just as the school librarian potentially serves as a sexual health information provider.

\section{Research Questions}

Through two separate studies conducted in Texas, a state in the southern part of the United States of America, three groups of people, two who supervise school librarians and then school librarians themselves, responded to the following research questions:

\section{Study 1}

Do district level library coordinators and campus level principals in Texas public school districts perceive high school librarians as playing the role of sexual health information providers?

What factors do these participants perceive as influencing librarians' role as sexual health information providers?

\section{Study 2}

Do high school librarians in Texas public school districts perceive themselves as playing the role of sexual health information providers? 
What factors do these participants perceive as influencing their role as sexual health information providers?

\section{Methods}

- The following definitions clarify terms frequently used in the methods section of this article:

- Public school - schools funded by state governments; all students, beginning at age 5 years and concluding at approximately the age of 18 years may attend public school for free.

- High school - schools serving students typically $14-18$ years of age

- School district - multiple schools within one town consolidate under a single administrative entity

- Campus - each individual school building within a school district

- District-level library coordinator - a certified school librarian who serves as an administrator for all librarians in the district; although district-level library coordinators supervise all campus librarians, the campus librarians do not report directly to the district-level library coordinator.

- High school campus principal - the administrator of each campus who also serves as liaison between the campus and the district-level administration; campus librarians report directly to the principal

- School librarian - a professional who must have a high school degree, a college degree, two years of teaching experience in the state of Texas, a Master's degree with a School Library Certification in Texas, and who has passed a state-mandated certification test. Depending on the school district, a school librarian may serve one or more campuses.

\section{Sample and site}

The state of Texas was selected due to its high birth rates and pregnancy rates, as well as its focus on abstinence education if and when sexual health education curriculum is taught.

For the first study, two participant groups were selected: high school campus principals and district-level library coordinators. These two participant groups were selected because both supervise and interact with campus librarians but potentially have different experiences with multiple facets of the school library and librarians.

Texas is the second largest state in the United States. Due to its size, the study was webbased so representation from multiple geographical areas within Texas would be represented. Participants received a link to each survey. The only identifying information requested was the participant's position (district-level library coordinator or principal). No other identifying information was collected, including names, locations, or IP addresses. 


\section{Data Collection and Analysis}

The Delphi method was used to collect data. With the Delphi method, data is generated over multiple rounds, seeking a consensus among participants. In the first round participants provide qualitative data by answering open-ended questions. The themes generated from content analysis form the quantitative survey statements for subsequent rounds. The survey items are grounded in participant responses instead of being prescribed by a pre-fabricated instrument (Cline, 2000; Colton \& Hatcher, 2004).

The second round introduces Likert scale statements based on themes from round one, indicating a level of agreement which correspond to the numbers 5-0, respectively: Strongly agree; Agree; Neither agree nor disagree; Disagree; Strongly disagree. As to not skew the data, respondents having no experience with the statement's theme are asked to select "Not Applicable." Upon analyzing the data, any question for which participants arrive at a consensus is removed from the questionnaire. A new questionnaire is generated for a third round, and the statements for which a consensus was not generated in round two are reworded and submitted again. The survey concludes when either a consensus has been reached or the data suggests a consensus will not be reached (Keeney, McKenna, \& Hasson, 2010).

For the first study, 13 high school principals participated in round one, and 10 participated in rounds two and three. Sixteen district-level library coordinators participated in round one, and 15 participated in rounds two and three. For the second study, 24 high school librarians participated in all three rounds.

Round one for both studies consisted of the same three open-ended questions asking participants if they perceived the school librarians as playing the role of sexual health information provider, to identify factors they perceive encourage sexual health information provision, and to identify factors they perceive discourage sexual health information provision. Participants provided narrative responses, and content analysis was used to generate themes for the development of statements for round two.

The data collection and analysis methods in round two for both studies were the same. The instrument's statements were based on themes generated from the open-ended responses in round one. Descriptive statistics were used to determine if a consensus had been reached: a mean of $3.8-5.0$ or a mean of $1.0-2.2$ equaled a consensus $(70.0 \%$ agreement or disagreement). Depending on how the statement was written, statements for which participants arrived at a consensus were listed as factors either encouraging or discouraging sexual health information provision. The instruments for the first study and the second study differed, however. In the first study, the themes generated from round one for both principals and district-level library coordinators were merged into one instrument. For the second study, the campus librarians responded to statements that were generated only from their responses to round one.

For round three, surveys in both studies were revised to include only those statements where consensus was not reached in round two. Each statement was rewritten. Two separate instruments were required for round three in the first study, however. District-level library coordinators received one instrument tailored to their responses in round two, and principals received a different instrument tailored to their responses in round two because the 
responses between the two groups varied greatly and because the majority of the principals remained neutral on all statements. For the second study, participants again responded to Likert scale statements specific to their responses in their round one. As with round two, descriptive statistics were used to analyze the data. To reach consensus, a statement's response must have a mean of $3.8-5.0$ or $1.0-2.2$, or $70.0 \%$. For both studies, data collection concluded with round three.

\section{Findings}

For both studies, participants were initially asked if they perceive high school librarians as playing the role of sexual health information providers. The two participant groups working in the library field overwhelmingly perceived high school librarians as playing this role compared to high school principals, as shared in Table 1.

\begin{tabular}{|l|l|l|l|}
\hline Response & $\begin{array}{l}\text { District-level } \\
\text { Library } \\
\text { Coordinators }\end{array}$ & $\begin{array}{l}\text { High School } \\
\text { Principals }\end{array}$ & $\begin{array}{l}\text { High School } \\
\text { Librarians }\end{array}$ \\
\hline Yes & $13(81.25 \%)$ & $3(23.10 \%)$ & $19(79.17 \%)$ \\
\hline No & $2(12.50 \%)$ & $7(53.80 \%)$ & $1(4.17 \%)$ \\
\hline Maybe & $0(0.00 \%)$ & $1(7.70 \%)$ & $0(0.00 \%)$ \\
\hline Other & $1(6.25 \%)$ & $2(15.40 \%)$ & $4(16.67 \%)$ \\
\hline
\end{tabular}

Table 1: Participants' Perceptions of the School Librarian's Role as a Sexual Health Information Provider

Participants identified a total of 19 motivators, or factors that encourage information provision, and six barriers, or factors that discourage information provision. Table 2 is arranged so that within the top portion of each column, commonalities between each group's responses are aligned. Below the dashed lines are responses unique to that participant group.

\begin{tabular}{|c|c|c|c|}
\hline & $\begin{array}{l}\text { District-level Library } \\
\text { Coordinators }\end{array}$ & $\begin{array}{l}\text { High School } \\
\text { Principals }\end{array}$ & $\begin{array}{l}\text { High School } \\
\text { Librarians }\end{array}$ \\
\hline Motivators & $\begin{array}{l}\text { Adolescents' lack of } \\
\text { knowledge } \\
\text { Confidentiality of } \\
\text { patron circulation } \\
\text { records } \\
\text { Job responsibility } \\
\text { Librarian-as- } \\
\text { information-provider } \\
\text { Patrons' personal } \\
\text { information needs } \\
\text { Rapport between } \\
\text { librarian and patrons } \\
\text { Availability of time for } \\
\text { collection } \\
\text { development } \\
\text { Patrons' curricular } \\
\text { information needs }\end{array}$ & $\begin{array}{l}\text { Librarian-as- } \\
\text { information-provider } \\
\text { Availability of time for } \\
\text { collection } \\
\text { development } \\
\text { Patrons' curricular } \\
\text { information needs } \\
\text {------------ }\end{array}$ & $\begin{array}{l}\text { Adolescents' lack of } \\
\text { knowledge } \\
\text { Confidentiality of } \\
\text { patron circulation } \\
\text { records } \\
\text { Job responsibility } \\
\text { Librarian-as- } \\
\text { information-provider } \\
\text { Patrons' personal } \\
\text { information needs } \\
\text { Rapport between } \\
\text { librarian and student }\end{array}$ \\
\hline
\end{tabular}




\begin{tabular}{|c|c|c|c|}
\hline & $\begin{array}{l}\text { District-level Library } \\
\text { Coordinators }\end{array}$ & $\begin{array}{l}\text { High School } \\
\text { Principals }\end{array}$ & $\begin{array}{l}\text { High School } \\
\text { Librarians }\end{array}$ \\
\hline & $\begin{array}{l}\text { Access to information } \\
\text { Appropriateness of } \\
\text { content within } \\
\text { resources } \\
\text { Availability of } \\
\text { resources } \\
\text { Emotional maturity of } \\
\text { patrons } \\
\text { Emphasis on } \\
\text { promoting resources } \\
\text { Physiological maturity } \\
\text { of patrons } \\
\text { Professional } \\
\text { guidelines }\end{array}$ & & $\begin{array}{l}\text { Campus population } \\
\text { behaviors } \\
\text { Collection } \\
\text { development } \\
\text { knowledge } \\
\text { Librarians } \\
\text { understanding of } \\
\text { information needs } \\
\text { Willingness to assist }\end{array}$ \\
\hline Barriers & $\begin{array}{l}\text { Librarians' personal } \\
\text { beliefs } \\
- \text { Conflict avoidance } \\
\text { Political climate } \\
\text { Reconsideration } \\
\text { request concerns }\end{array}$ & $\begin{array}{l}\text { Librarians' personal } \\
\text { beliefs } \\
\text { Legal Liability }\end{array}$ & Internet filters \\
\hline
\end{tabular}

Table 2: Findings, Motivators and Barriers, by Participant Group

High school principals do not work in the library; thus, their knowledge of the librarian's role of a sexual health information provider, as well as the library as a sexual health learning environment, could be limited based on myriad factors. District-level library coordinators identified more motivators and barriers to information provision than did campus librarians. While no data currently exists to explain why, one could only speculate that it is because this participant group manages multiple campuses' libraries and thus has more exposure to possible motivators and barriers.

\section{Discussion}

All three participant groups identified more motivators for sexual health information provision than barriers in Texas, but participant groups provided conflicting responses regarding the role of the school librarian as a sexual health information provider. Because of such small participant groups and because the participants only represented the population of Texas, the results cannot be generalized to other states, to the United States, nor to any country outside of the United States.

AASL's Empowering Learners (2009) identifies school librarians as playing the roles of leaders, teachers, information specialists, instructional partners, and program administrators. Some of the responsibilities within these roles include (1) advocating for their adolescent patrons' information needs; (2) teaching students how to locate and evaluate high-quality, 
accurate, and current information; (3) providing access to a variety of resources in a multiple formats; (4) teaching curriculum-based lessons; and (5) meeting the personal and curricular information needs of their adolescent patrons. Participants in this study identified motivators to sexual health information provision within the library including personal information needs, curricular information needs, the librarian as an information provider, access and availability of resources, advocacy of resources, all of align within the five roles. As such, it is possible that the school librarian can serve as a sexual health information provider.

According to IASL's Policy Statement on School Libraries (1993), ALA's Bill of Rights (2015), and AASL's Governing Documents (2015), the school library is a learning environment where students may access resources and materials for both curricular and personal information needs, providing accurate, reliable, and current information representing multiple perspectives. Sexual health information is both a curricular and personal information need in the United States. High school libraries provide the benefits of formal sources yet can provide a variety of materials with the appeal of informal sources. Additionally, school library collections, both print and digital, offer information found within comprehensive sexual education programs. The school librarian is a teacher, and the school library is a campuswide classroom; thus, the school library can serve as a sexual health learning environment. Further research, however, is needed.

\section{Conclusion}

Human sexuality is complex. Physiological, emotional, psychological, cultural, religious, educational, and societal factors contribute to an adolescent's sexual health attitudes and behaviors. Despite its complexity, adolescents who receive current, accurate, reliable, and balanced sexual health information are more likely to express healthier sexual attitudes and engage in healthier sexual behaviors than adolescents receiving limited, inaccurate, or no sexual health information. High school librarians as sexual health information providers and high school libraries as sexual health learning environments can potentially promote healthy decision-making among adolescents.

\section{References}

Advocates for Youth. (2008). Adolescent sexual health in Europe and the US. Retrieved from http://www.advocatesforyouth.org/publications/419?task=view.

Alan Guttmacher Institute. (2001). Can more progress be made? Teenage sexual and reproductive behavior in developed countries. Retrieved from http://www.guttmacher.org/pubs/summaries/euroteens summ.pdf.

Alan Guttmacher Institute. (2015). State policies in brief: Sex and STI/HIV

Education. Retrieved from http://www.guttmacher.org/statecenter/spibs/spib SE.pdf.

American Association of School Librarians. (2009). Empowering learners: Guidelines for school library programs. Chicago: American Library Association.

American Association of School Librarians. (2015). AASL governing documents. Retrieved from http://www.ala.org/aasl/about/governing-docs. 
American Library Association. (2015). Library Bill of Rights. Retrieved from http://www.ala.org/advocacy/intfreedom/librarybill.

Bleakley, A., Hennessy, M. Fishbein, M., \& Jordan, A. (2009). How sources of sexual information relate to adolescents' beliefs about sex. American Journal of Health Behavior, 33(1), 37-48.

Boonstra, H. (2011). Advancing sexuality education in developing countries: Evidence and implications. Retrieved from https://www.guttmacher.org/pubs/gpr/14/3/gpr140317.html.

Centers for Disease Control and Prevention. (2014a). Youth risk behavior surveillanceUnited States, 2013, 63(4). Retrieved from http://www.cdc.gov/mmwr/pdf/ss/ss6304.pdf.

Centers for Disease Control and Prevention. (2014b). Texas, high school youth risk behavior survey, 2013. Youth Online. Retrieved from http://nccd.cdc.gov/YouthOnline/App/Results.aspx?LID=TX.

Cline, A. (2000). Prioritization process using Delphi technique (White Paper). Carolla Development. Retrieved from http://www.carolla.com/wp-delph.htm.

Colton, S. \& Hatcher, T. (2004). The web-based Delphi technique as a method for content validation in HRD and adult education research. Retrieved from http://files.eric.ed.gov/fulltext/ED492146.pdf.

Cornog, M. \& Perper, T. (1996). For sex education, see librarian: A guide to issues and resources. Westport, Conn.: Greenwood Press.

Hoff, T., \& Greene, T. (2000). Sex education in America: A series of national surveys of students, parents, teachers, and principals. Retrieved from https://kaiserfamilyfoundation.files.wordpress.com/2000/09/3048-sex-education-inamerica-a-view-from-inside-the-nations-classrooms.pdf.

Hoffman, S., Foster, E., \& Furstenberg, F. (1993). Reevaluating the costs of teenage childbearing. Demography, 30(1), 1-13.

International Association of School Librarianship. (1993). IASL policy statement on school libraries. Retrieved from http://iasl-

online.mlanet.org/about/organization/sl policy.html.

Keeney, S., McKenna, H., \& Hasson, F. (2010). The Delphi technique in nursing and health research. Chichester: John Wiley and Sons, Ltd.

Kirby, D. (2007). Emerging answers 2007: Research findings on programs to reduce teen pregnancy and sexually transmitted diseases. Retrieved from https://thenationalcampaign.org/sites/default/files/resource-primarydownload/EA2007 full 0.pdf. 
Kost, K., and Henshaw, S. (2014). U.S. teenage pregnancies, births and abortions, 2010:

National and state trends by age, race and ethnicity. Retrieved from https://www.guttmacher.org/pubs/USTPtrends10.pdf.

Landry, D., Darroch, J., Singh, S., \& Higgins, J. (2003). Factors associated with the content of sex education in U.S. public secondary schools. Perspectives on Sexual and Reproductive Health, 35(6), 261-269.

Moore, K., Morrison, D., \& Greene, A. (1997). Effects on the children born to adolescent mothers. In R. Maynard (Ed.), Kids having kids: Economic costs and social consequences of teen pregnancy (145-180). Washington, DC: Urban Institute.

National Campaign to Prevent Teen and Unplanned Pregnancy. (2015a). Counting it up: The public costs of teen childbearing. Retrieved from https://thenationalcampaign.org/why-it-matters/public-cost.

National Campaign to Prevent Teen and Unplanned Pregnancy. (2015b). Counting it up: The public costs of teen childbearing in Texas in 2010. Retrieved from https://thenationalcampaign.org/sites/default/files/resource-primary-download/factsheet-texas.pdf.

Sexuality Information and Education Council of the United States. (n.d.) Fact sheet: What the research says...comprehensive sex education. Retrieved from http://www.siecus.org/index.cfm?fuseaction=Page.ViewPage\&PagelD=1193.

Singh, S., \& Darroch, J. (2000). Adolescent pregnancy and childbearing: Levels and trends in developed countries. Family Planning Perspectives, 32(1),14-23.

Social Security Administration. (2009). Compilation of the Social Security Laws: Separate program for abstinence education, Section 510. Retrieved from http://www.ssa.gov/OP Home/ssact/title05/0510.htm.

Somers, C. \& Surmann, A. (2005). Sources and timing of sex education: Relations with American adolescent sexual attitudes and behaviour. Educational Review, 57(1), 37-54.

\section{Biographical note}

Jennifer Richey has worked as an Assistant Professor at Texas Woman's University's School of Library and Information Studies in Denton, Texas since 2011 where she teaches courses focusing school library certification, young adult literature, and youth library programs. Her primary research interest is on health information literacy of adolescents. Prior to that, she was an elementary school librarian in the Austin, Texas area. 